\title{
Performance of Coloured Broilers with and without Enzymes Supplementation Fed SFC Included Varying Crude Fibre Diets
}

\author{
Laxmi Chouhan $^{1}$, S. S. Atkare ${ }^{1 *}$, A. S. Shinde ${ }^{2}$, S. K. Joshi ${ }^{3}$ and L. S. Shekhawat ${ }^{2}$ \\ ${ }^{1}$ Department of Poultry Science, College of Veterinary Science and Animal \\ Husbandry, N.D.V.S.U., Jabalpur, India \\ ${ }^{2}$ Instructional Dairy Unit, College of agriculture, J.N.K.V.V., Jabalpur, India \\ ${ }^{3}$ Department of Animal Genetics and Breeding, N.D.V.S.U., Jabalpur, India \\ *Corresponding author
}

Keywords

Colour broilers,

SFC, Crude fiber,

Enzymes,

Performance traits,

etc

Article Info

Accepted:

07 October 2020

Available Online:

10 November 2020

\section{A B S T R A C T}

Diet containing 5\% crude fibre (CF) was incorporated with $20 \%$ and $40 \%$ Sun flower meal (SFC) by replacing Soybean meal (SBM) to prepare 7 and $9 \% \mathrm{CF}$ diet and supplemented with desired lysine and methionine. Counter part of each diet having enzyme mixture (cellulase 300000 IU, B glucanase 2,50,000 IU, Xylanase 300000 IU, Lipase $14000 \mathrm{IU}$ and amylase 75,000 IU ) at level of $\mathrm{E}_{0}$ (without enzyme), $\mathrm{E}_{1}(25 \mathrm{~g} / 100 \mathrm{~kg}$ ) and $\mathrm{E}_{2}(50 \mathrm{~g} / 100 \mathrm{~kg})$. All diets containing $22 \% \mathrm{CP}$ in starter phase and $21 \% \mathrm{CP}$ in finisher phase. Feed intake (FI) and body weight were significantly $(\mathrm{P}<0.05)$ higher in $7 \%$ CF diet than $5 \%$ and $9 \% \mathrm{CF}$ diet. $\mathrm{E}_{1}$ and $\mathrm{E}_{2}$ enzymes in each $\mathrm{CF}$ diet significantly $(\mathrm{P}<0.05)$ improved feed intake and body weight. Treatment $\mathrm{CF}_{3} \times \mathrm{E}_{2}$ had higher feed intake with non significant difference from $\mathrm{CF}_{3} \times \mathrm{E}_{1}$ and $\mathrm{CF}_{2} \times \mathrm{E}_{2}$. Body weight was higher in $\mathrm{CF}_{2} \times \mathrm{E}_{2}$ with non significant difference from $\mathrm{CF}_{2} \times \mathrm{E}_{1}$ and $\mathrm{CF} 3 \times \mathrm{E} 2$. Increasing crude fiber level significantly $(\mathrm{P}<0.05)$ increases intestinal length, weight and viscosity whereas enzyme supplementation exerted counter effect on these traits. Excreta moisture increased significantly in $7 \%$ and $9 \% \mathrm{CF}$ diet and decreased with enzyme supplementation. Income over feed cost was highest in $\mathrm{CF}_{2} \times \mathrm{E}_{1}$ (Rs. 48.60) and lowest in $\mathrm{CF}_{3} \times \mathrm{E}_{0}$ (Rs.39.28) treatment.

\section{Introduction}

Soybean meal (SBM) is conventionally used protein source in poultry ration is costly ingredient hence some other oil cake is often used with it to reduce cost of feed. Sun flower meal (SFC) is good source of protein but could be included in lower level due to its high fiber contents (Senkoylu and Dale, 2006). Its oil seed is rich in methionine, $\alpha$ tocopherol, linolic acid, $\mathrm{Ca}, \mathrm{P}$ and cysteine
(Panda et al., 2004). In expeller dehulled SFC, crude fiber may be lowers up to $12 \%$ and Crude protein $(\mathrm{CP})$ content higher up to $32 \%$. Uses of NSP enzyme breakdown complex NSP content and increase caloric content of feed by $100-200 \mathrm{kcal} / \mathrm{kg}$ (Raza et al., 2009) and make easy access of endogenous proteolytic enzyme to digest plant protein. Inconsistent results are reported in literature regarding feeding of varying levels of crude fibre (CF) with enzyme 
supplementation on performance of broiler. The present study was therefore planning to investigate the effect of varying $\mathrm{CF}$ level by inclusion of SFC with or without commercial enzyme supplementation on performance of broilers.

\section{Materials and Methods}

One hundred eighty day old coloured commercial broiler chicks were randomly divided into nine dietary treatment groups. Each group had 20 birds in two replicates. Corn SBM based diet containing 5\% CF was replaced with SFC (20\% and $40 \%$ ) to prepare $7 \%$ and $9 \%$ CF diets. All diets containing 22 $\% \mathrm{CP}$ in starter phase and $21 \% \mathrm{CP}$ in finisher phase. Each $\mathrm{CF}$ diet was supplemented with 3 levels of enzyme mixture i.e. $\mathrm{E}_{0}$ (without enzyme $), \quad E_{1}(25 \mathrm{~g} / 100 \mathrm{~kg})$ and $\mathrm{E}_{2} \quad(50$ $\mathrm{gm} / 100 \mathrm{~kg}$ ) in a factorial designed experimentt. Commercial enzyme mixture containing cellulase 300000 IU, $\beta$ glucanase 25,0000 IU, xylanase $300000 \mathrm{IU}$, lipase 14,000 IU and amylase 75,000 IU. All diets were analysed for crude fiber contents protein and energy as per method (AOAC, 1995). SFC utilized in this study containing $13 \% \mathrm{CF}$, $37 \%$ protein and $2230 \mathrm{kcal} \mathrm{ME} / \mathrm{kg}$. Ingredients and supplements used in ration were maize, SBM, SFC, FM, mineral mixture, vitamin premix, LSP, DCP, methionine, lysine, chlorine chloride and coccidiostate. Weekly body weight and feed intake measured upto 6 weeks of age. At 6 week 2 males and 2 females were slaughtered from each replicate as per standard procedure, intestine was removed after ligation at two sides and its length measured in $\mathrm{cm}$ from meckle's diverticulum to iliocaecal junction and content of intestine was collected in glass vials, laced in icebox and empty weight of intestine was recorded and expressed as g. Homogenized digesta (2g) was taken in centrifuge tube containing $10 \mathrm{ml}$ of distilled water and centrifuged at $5000 \mathrm{rpm} / 15$ minuts.
The relative viscosity of digesta supernatant was measured as kinetic viscosity in centi stroke by Oswal U tube viscometer as per Choct and Annison (1992). Excreta moisture was determined by collecting representative sample of excreta from each replicate on last day of experiment by spreading polythene sheet on litter and its moisture estimated as per method (AOAC, 1995). Collected data analysed as per Snedecor and Cochran (1994).

\section{Results and Discussion}

\section{Feed intake}

Feed intake was significantly $(\mathrm{P}<0.05)$ high in $7 \% \mathrm{CF}$ diet $\left(\mathrm{CF}_{2} \times \mathrm{E}_{0}\right)$ than $5 \% \mathrm{CF}\left(\mathrm{CF}_{1} \times \mathrm{E}_{0}\right)$ and $9 \% \mathrm{CF}\left(\mathrm{CF}_{3} \times \mathrm{E}_{0}\right)$ diet. Increased NSP content in ration causes dilution of energy which result in higher FI of birds in $7 \% \mathrm{CF}$ diet. However, increasing $\mathrm{CF}$ up to $9 \%$ shown decreased FI of birds attributed to decreased palatability, increased bulkiness and viscosity in intestine result in impaired digestion and absorption of nutrients. The result was in agreement to Austin et al., (1999) and Naqui and Nadeem (2006). In each CF level supplementation of enzyme at $\mathrm{E}_{1}$ and $\mathrm{E}_{2}$ level result in significantly higher $(\mathrm{P}<0.05)$ feed intake than E0 without enzyme diet. This was in agreement with the fining of Swain et al (1996) and Nadeem et al., (2005). Enzymes causes disruptions in grain cell wall, increases nutrient availability, improve growth and feed intake of birds (Salin et al., 1991). Overall interaction results shown significantly higher $\mathrm{FI}$ in $\mathrm{CF}_{3} \times \mathrm{E}_{2}$ with non significant difference from $\mathrm{CF}_{3} \times \mathrm{F}_{1}$ and $\mathrm{CF}_{2} \times \mathrm{E}_{2}$ and significant from all other combinations.

\section{Body weight}

Dietary energy in $7 \% \mathrm{CF}$ diet and $9 \% \mathrm{CF}$ diet were $5.48 \%$ and $7.49 \%$ lower than $5 \% \mathrm{CF}$ diet. Compensation of lower energy with higher FI and supplementation of lysine 
methionine result in significantly $(\mathrm{P}<0.05)$ higher body weight in $7 \% \mathrm{CF}$ diet $\left(\mathrm{CF}_{2} \times \mathrm{E} 0\right)$ than $9 \%\left(\mathrm{CF}_{3} \times \mathrm{E}_{0}\right)$ and $5 \% \mathrm{CF}$ $\left(\mathrm{CF}_{1} \times \mathrm{E}_{0}\right)$ diets. Elzubair et al., (1991), Rama rao et al (2009) reported higher body weight in $7 \% \mathrm{CF}$ diet prepared with inclusion of SFC with SBM and supplemented with lysine and methionine. Similar fining with low energy $7 \%$ CF diet was reported by Channegowda et al., (2001). The present finding was in agreement to these authors. Lower body weight in $9 \% \mathrm{CF}$ diet might be due to decreased feed intake and increased digesta viscosity, consequently decreased digestion and utilization of nutrients. Supplementation of $E_{1}$ and $E_{2}$ enzymes in $\mathrm{CF}_{1}, \mathrm{CF}_{2}$ and $\mathrm{CF}_{3}$ diets improved body weight significantly $(\mathrm{P}<0.05)$ over its respective without enzyme diets i.e. $\mathrm{CF}_{1} \times \mathrm{E}_{0}, \mathrm{CF}_{2} \times \mathrm{E}_{0}$ and $\mathrm{CF}_{3} \times \mathrm{E}_{0}$. Higher body weight in enzymes supplemented diet was in accordance with the result of Garcia et al (2003) and Suman et al., (2009) (Table 1).

Table.1 Effect of crude fibre and enzymes on feed intake, body weight and Intestinal parameters of colour broilers

\begin{tabular}{|l|l|l|l|l|l|l|}
\hline Treatments & $\begin{array}{l}\text { Feed } \\
\text { intake }\end{array}$ & $\begin{array}{l}\text { Body } \\
\text { weight }\end{array}$ & $\begin{array}{l}\text { Intestinal } \\
\text { length } \\
\text { (cm) }\end{array}$ & $\begin{array}{l}\text { Intestinal } \\
\text { weight }(\mathbf{g})\end{array}$ & $\begin{array}{l}\text { Digesta } \\
\text { viscosity }\end{array}$ & $\begin{array}{l}\text { Excreta } \\
\text { moisture (\%) }\end{array}$ \\
\hline $\mathbf{C F}_{\mathbf{1}} \mathbf{X E}_{\mathbf{0}}$ & $3078.7^{\mathrm{e}}$ & $1362.3^{\mathrm{d}}$ & $11.24^{\mathrm{d}}$ & $4.19^{\mathrm{d}}$ & $1.28^{\mathrm{c}}$ & $71.38^{\mathrm{abc}}$ \\
\hline $\mathbf{C F}_{\mathbf{2}} \mathbf{X E}_{\mathbf{0}}$ & $3264.8^{\mathrm{c}}$ & $1420.5^{\mathrm{c}}$ & $12.71^{\mathrm{b}}$ & $5.20^{\mathrm{b}}$ & $1.36^{\mathrm{b}}$ & $74.25^{\mathrm{de}}$ \\
\hline $\mathbf{C F}_{\mathbf{3}} \mathbf{X E}_{\mathbf{0}}$ & $3036.0^{\mathrm{e}}$ & $1300.0^{\mathrm{e}}$ & $13.18^{\mathrm{a}}$ & $5.34^{\mathrm{a}}$ & $1.42^{\mathrm{a}}$ & $75.75^{\mathrm{e}}$ \\
\hline $\mathbf{C F}_{\mathbf{1}} \mathbf{X E}_{\mathbf{1}}$ & $3135.0^{\mathrm{d}}$ & $1399.0^{\mathrm{c}}$ & $11.14^{\mathrm{d}}$ & $4.18^{\mathrm{d}}$ & $1.23^{\mathrm{f}}$ & $69.38^{\mathrm{a}}$ \\
\hline $\mathbf{C F}_{\mathbf{2}} \mathbf{X E}_{\mathbf{1}}$ & $3290.3^{\mathrm{b}}$ & $1467.8^{\mathrm{ab}}$ & $12.03^{\mathrm{c}}$ & $4.89^{\mathrm{c}}$ & $1.26^{\mathrm{cde}}$ & $71.25^{\mathrm{abc}}$ \\
\hline $\mathbf{C F}_{\mathbf{3}} \mathbf{X E}_{\mathbf{1}}$ & $3365.0^{\mathrm{b}}$ & $1456.5^{\mathrm{b}}$ & $12.15^{\mathrm{c}}$ & $4.88^{\mathrm{c}}$ & $1.28^{\mathrm{c}}$ & $72.50^{\mathrm{cd}}$ \\
\hline $\mathbf{C F}_{\mathbf{1}} \mathbf{X E}_{\mathbf{2}}$ & $3145.5^{\mathrm{d}}$ & $1410.5^{\mathrm{c}}$ & $10.96^{\mathrm{d}}$ & $4.11^{\mathrm{d}}$ & $1.23^{\mathrm{f}}$ & $70.00^{\mathrm{ab}}$ \\
\hline $\mathbf{C F}_{\mathbf{2}} \mathbf{X E}_{\mathbf{2}}$ & $3368.5^{\mathrm{ab}}$ & $1484.0^{\mathrm{a}}$ & $11.96^{\mathrm{c}}$ & $4.84^{\mathrm{c}}$ & $1.24^{\mathrm{ef}}$ & $70.00^{\mathrm{ab}}$ \\
\hline $\mathbf{C F}_{\mathbf{3}} \mathbf{X E}_{\mathbf{2}}$ & $3398.6^{\mathrm{a}}$ & $1465.0^{\mathrm{ab}}$ & $12.11^{\mathrm{c}}$ & $4.86^{\mathrm{c}}$ & $1.25^{\mathrm{det}}$ & $72.00^{\mathrm{bc}}$ \\
\hline
\end{tabular}

Means in a column with uncommon superscripts are significant $(\mathrm{P}<0.05)$

Table.2 Economics of rearing colour broiler fed high fibre diet with and without enzyme

\begin{tabular}{|c|c|c|c|c|c|c|c|c|c|}
\hline \multirow[t]{2}{*}{ Treatment } & \multicolumn{3}{|c|}{ Starter phase (0-3 weeks) } & \multicolumn{3}{|c|}{ Finisher phase (4-6 weeks) } & \multirow{2}{*}{$\begin{array}{l}\text { Total } \\
\text { feeding } \\
\text { cost }\end{array}$} & \multirow{2}{*}{$\begin{array}{l}\text { Sale of } \\
\text { birds } \\
@ \text { Rs. } \\
\text { 100/kg }\end{array}$} & \multirow{2}{*}{$\begin{array}{l}\text { Income } \\
\text { over } \\
\text { feeding } \\
\text { cost (Rs.) }\end{array}$} \\
\hline & $\begin{array}{l}\text { Feed } \\
\text { Intake } \\
\text { (kg) }\end{array}$ & $\begin{array}{l}\text { Feed } \\
\text { cost/kg } \\
(\text { Rs. })\end{array}$ & $\begin{array}{l}\text { Feeding } \\
\text { cost } \\
(\mathbf{R s} .)\end{array}$ & $\begin{array}{l}\text { Feed cost } \\
\text { per kg } \\
\text { (Rs.) }\end{array}$ & $\begin{array}{l}\text { Feed } \\
\text { intake } \\
(\mathrm{kg})\end{array}$ & $\begin{array}{l}\text { Feedin } \\
\text { g cost } \\
\text { (Rs.) }\end{array}$ & & & \\
\hline $\mathrm{CF}_{1} \mathrm{XE}_{\mathbf{0}}$ & 0.975 & 31.10 & 29.34 & 30.39 & 2.10 & 63.97 & 93.25 & 136.2 & 42.95 \\
\hline $\mathrm{CF}_{2} \mathrm{XE}_{0}$ & 1.033 & 30.32 & 31.32 & 29.48 & 2.23 & 65.74 & 97.06 & 142.0 & 44.94 \\
\hline $\mathrm{CF}_{3} \mathrm{XE}_{0}$ & 0.956 & 31.51 & 30.09 & 29.20 & 2.08 & 60.73 & 90.82 & 130.0 & 39.28 \\
\hline $\mathrm{CF}_{1} \mathrm{XE}_{1}$ & 0.977 & 30.21 & 30.49 & 30.50 & 2.15 & 60.57 & 96.06 & 139.9 & 43.84 \\
\hline $\mathrm{CF}_{2} \mathrm{XE}_{1}$ & 1.134 & 31.43 & 34.50 & 25.59 & 2.15 & 63.61 & 98.11 & 146.7 & 48.60 \\
\hline $\mathrm{CF}_{3} \mathrm{XE}_{1}$ & 1.004 & 31.62 & 31.74 & 29.31 & 2.36 & 69.17 & 100.91 & 145.6 & 44.70 \\
\hline $\mathrm{CF}_{1} \mathrm{XE}_{2}$ & 1.023 & 31.32 & 32.04 & 30.61 & 2.12 & 64.89 & 96.93 & 141.0 & 44.07 \\
\hline $\mathrm{CF}_{2} \mathrm{XE}_{2}$ & 1.069 & 30.54 & 32.64 & 29.70 & 2.29 & 68.01 & 100.65 & 148.4 & 44.75 \\
\hline $\mathrm{CF}_{3} \mathrm{XE}_{2}$ & 1.025 & 31.73 & 32.52 & 29.42 & 2.37 & 69.72 & 102.24 & 146.5 & 44.20 \\
\hline
\end{tabular}


Overall interaction results shown highest body weight in $\mathrm{CF}_{3} \times \mathrm{E}_{2}$ with non significant difference from $\mathrm{CF}_{2} \times \mathrm{E}_{1}$ and $\mathrm{CF}_{2} \times \mathrm{E}_{2}$. Significant CF x Enzyme interaction for body weight was reported by Shrivastava et al., (2005). Intestine parameters significantly $(\mathrm{P}<0.05)$ higher intestinal length (l) and Weight (wt.)with increasing CF in diet was in agreement with the result of Ikegami et al., (1990) and Berwal et al., (2008). Enzyme supplementation in 5\% CF diet did not cause any difference in length and weight of intestine i.e. $\mathrm{CF}_{1} \times \mathrm{E}_{0}, \mathrm{CF}_{1} \times \mathrm{E}_{1}$ and $\mathrm{CF}_{1} \times \mathrm{E}_{2}$ were similar whereas in $7 \%$ and $9 \% \mathrm{CF}$ diets, $\mathrm{E}_{1}$ and $\mathrm{E}_{2}$ enzyme supplementation result in significantly decreased length and weight of intestine than its respective without enzyme diets $\left(\mathrm{CF}_{2} \times \mathrm{E}_{0}\right.$ and $\left.\mathrm{CF}_{3} \times \mathrm{E}_{0}\right)$. This finding was in agreement with Berwal et al., (2008) and Barathidhasan et al., (2009). Interaction results shown significantly $(\mathrm{P}<0.05)$ highest length and weight of intestine in $\mathrm{CF}_{3} \times \mathrm{E}_{0}$ and lowest in $\mathrm{CF}_{1} \times \mathrm{E}_{2}$ with non significant difference from $\mathrm{CF}_{1} \times \mathrm{E}_{0}$ and $\mathrm{CF}_{1} \times \mathrm{E}_{1}$. Intestinal viscosity (vs) increased significantly $(\mathrm{P}<0.05)$ with increasing $\mathrm{CF}$ levels from $\mathrm{CF}_{1} \times \mathrm{E}_{0}$ to $\mathrm{CF}_{2} \times \mathrm{E}_{0}$ and $\mathrm{CF}_{3} \times \mathrm{E}_{0}$. The result was in accordance with Nisha (2005), Udeybir et al., (2007), Rajesh et al., (2006) and Berwal et al., (2008). Overall interaction result shown significantly higher intestinal viscosity in $\mathrm{CF}_{3} \times \mathrm{E}_{0}$ and significantly lowest in $\mathrm{CF}_{1} \times \mathrm{E}_{1}, \mathrm{CF}_{1} \times \mathrm{E}_{2}$, $\mathrm{CF}_{3} \times \mathrm{E}_{2}$ with non significant difference between them. Excreta moisture increased significantly $(\mathrm{P}<0.05)$ with increasing dietary crude fibre from $5 \%\left(\mathrm{CF}_{1} \times \mathrm{E}_{0}\right)$ to $7 \%$ $\left(\mathrm{CF}_{2} \times \mathrm{E}_{0}\right)$ and $9 \%\left(\mathrm{CF}_{3} \times \mathrm{E}_{0}\right) . \quad \mathrm{E}_{1}$ and $\mathrm{E}_{2}$ enzyme supplementation significantly decreased excreta moisture in $7 \%$ and $9 \% \mathrm{CF}$ diet than its without enzyme diets $\left(\mathrm{CF}_{2} \times \mathrm{E}_{0}\right.$ and $\mathrm{CF}_{3} \times \mathrm{E}_{0}$ ). The result was in collaboration with Nisha (2005) and Udeybir et al (2007). Supplementation of enzyme significantly decreased intestinal viscosity. Similar effect of enzymes on intestinal viscosity was reported by Rajesh et al., (2005) and Berwal et al., (2008). Overall interaction shown highest excreta moisture in $\mathrm{CF}_{3} \times \mathrm{E}_{0}$ and lowest in $\mathrm{CF}_{1} \times \mathrm{E}_{2}$. Economics of rearing is presented in Table 2. Economics of feeding cost rearing upto 6 week was found highest in $\mathrm{CF}_{3} \times \mathrm{E}_{2}$ (Rs. 102.24) and lowest in $\mathrm{CF}_{3} \times \mathrm{E}_{0}$ (Rs. 90.82). Income per bird on sale was higher in $\mathrm{CF}_{2} \times \mathrm{E}_{2}$ (Rs. 148.40) and subsequent to this was $\mathrm{CF}_{2} \times \mathrm{E}_{1}$ (Rs. 146.70) and $\mathrm{CF}_{3} \times \mathrm{E}_{2}$ (Rs.146.40). Gross return over feeding expenditure was highest in $\mathrm{CF}_{2} \times \mathrm{E}_{1}$ (Rs. 48.60) and lowest in $\mathrm{CF}_{3} \times \mathrm{E}_{0}$ (Rs. 39.28).

In conclusion the feed intake (FI) and body weight were significantly $(\mathrm{P}<0.05)$ higher in 7 $\% \mathrm{CF}$ diet than $5 \%$ and $9 \% \mathrm{CF}$ diet. $\mathrm{E}_{1}$ and $\mathrm{E}_{2}$ enzymes in each $\mathrm{CF}$ diet significantly $(\mathrm{P}<0.05)$ improved feed intake and body weight. Treatment $\mathrm{CF}_{3} \mathrm{X} \mathrm{E}_{2}$ had higher feed intake with non significant difference from $\mathrm{CF}_{3} \times \mathrm{E}_{1}$ and $\mathrm{CF}_{2} \times \mathrm{E}_{2}$. Body weight was higher in $\mathrm{CF}_{2} \times \mathrm{E}_{2}$ with non significant difference from $\mathrm{CF}_{2} \times \mathrm{E}_{1}$ and $\mathrm{CF} 3 \times \mathrm{E} 2$. Increasing crude fiber level significantly $(\mathrm{P}<0.05)$ increases intestinal length, weight and viscosity whereas enzyme supplementation exerted counter effect on these traits. Excreta moisture increased significantly in $7 \%$ and 9\% CF diet and decreased with enzyme supplementation. Income over feed cost was highest in $\mathrm{CF}_{2} \times \mathrm{E}_{1}$ (Rs. 48.60) and lowest in $\mathrm{CF}_{3} \times \mathrm{E}_{0}(\mathrm{Rs} .39 .28)$ treatment.

\section{References}

Annision, G. (1992). Commercial enzyme supplementation of wheat based diets raises ileal glycanase activities and improves apparent metabolizable energy, starch and pentosan digestibilities in broiler chickens. Animal feed science technology, 38:105-121. 
AOAC (1995). Official methods of Analytical Chemists. 16th Edn. Arlington, V.A.USA.

Austin, S.C., Wiseman, J., Chesson, A. (1999). Influence of non-starch polysaccharides structure on the metabolizable energy of U.K. wheat fed to poultry. Journal of cereal science, 29:77-78.

Berwal, R. S., Lohan, O. P. and Sihag, Z. S. (2008). Effect of dietary crude fibre levels and enzyme supplementation on performance and carcass characteristics of broiler chicks. Indian Journal of Poultry Science, 43(2): 179-83.

Bharathidhasan, A., Chandrasekaran, D. Natrjan, A. Rav, R. and Ezhivalvan, S. (2009). Effect of enzyme supplementation on carcass quality, intestinal viscosity and ileal digestibilities of broilers to nutrient reduced diet. Tamilnadu Journal of Veterinary and Animal Science, 5(6): 239-245.

Channegowda, H.K., Gowdh, C.V. and Devegowda, G. (2001). Efficacy of enzyme mixture to improve performance of broilers fed sunflower extraction rich diets. Indian Journal of Poultry Sciience, 36: 256-259.

El Zubeir, E. A. and Ibrahim, M. A. (1991). Effect of dietary full-fat raw sunflower seed on performance and carcass skin color of broilers. Journal of Science Food and Agriculture, 55 (3): 479-481.

Gracia , M. I., Araníbar, M. J., Lázaro, R., Medel, P., Mateos, G. G. (2003). Alpha-amylase supplementation of broiler chicks fed on barley based diet. Swedish Journal of Agriculture Research, 22: 39-42.

Ikegami, S., Tsuchuhashi, F., Harada, H., Tsuchuhashi, N., Nishide, E. and Innami S. (1990). Effect of viscous indigestible polysaccharides on pancreatic-biliary secretion and digestive organs in rats. Journal of Nutrition, 120: 353-360.

Nadeem, M.A., Anjum, M.I., Khan, A.J. and Azim, A. (2005). Effect of dietary supplementation of non starch polysaccharide degrading enzymes on growth performance of broiler chicks. Pakistan Veterinary Journal, 24(2): 98-100.

Naquvi, L.U. and Nadeem, A. (2006). Bioavilability of metabolizable energy through Kimzyme supplementation in broiler ration. Pakistan Veterinary Journal, 24 (2), 98-100.

Nisha, J. (2005). Effect of pearl millets and sunflower meal with enzyme supplementation on the performance of broilers. M.V.Sc. Thesis. Chaudhary Charan Singh, Agriculture University, Haryana, Hisar.

Rajesh, M.M. Reddy, P.S. Reddy, S.M. (2006). Effect of sunflower meal with or without enzyme mixture on the performance of broilers. Proccedings XXIV IPSACON 2-4 februray. Hyderabad.

Ramarao, S.V. Raju, M.V.L.M., Panda, A.K., Poonam, M.S., Shyam Sunder, G. and Sharma, R.P. (2009). Utilization of sunflower seed meal in Vanraja Chicken diet. Indian Journal of Poultry Science, 44(3): 392-395.

Raza, S.M. Ashraf, M., Pasha, T.M. and Latif, F. (2009). Effect of enzyme supplementation of broiler diets containing varying level of sunflower meal and crude fiber. Pakistan Journal of Botany, 41(5); 2543-2550.

Salih, M.E., Classeh, H.L. and Campbell, G.I. (1991).Response of chickens fed on hull-less barley to dietary $\beta$-glucanase at different ages. Animal Feed Science and Technology, 33: 139- 
149.

Senkoylu, N.E., Akyurek, H., Samil, H.E., Ekten, E. and Kayham, A. (1997). The effect of high energy protein sunflower meal on broiler performance. Proceedings of 11th European WPSA Symposium on Poultry Nutrition.

Snedecor, G.W. and Cochran, W.G. (1994). Statistical methods. 8th Edn. The Iowa State University Press Ames, IOWA, U.S.A.

Srivastava, S.P., Singh, S. and Saraswat, B.L. (2005). Effect of enzyme supplementation in high fibre diet on the performance of broilers. Indian Journal of Animal Nutrition, 32(1): 13-15.

Suman, R., Tyagi, Promod K., Shrivastav, A.K., Tyagi, Praveen K. and Mandal, A.B. (2009). Effect of feeding sunflower meal with or without enzyme supplementation and acidified sodium chloride on growth performance and nutrient utilization in broiler chicken. Indian Journal of Poultry Science, 44: 335-41.

Swain, B.K., Johri, T.S. Shrivastav, A.K. and S. Majumdar. (1996). Performance of broilers fed on high or low fibre diets supplemented with digestive enzymes. Journal of Applied Animal Research, 10: 95-102.

Udeybir, K.R., Yadav, B.S., Teurtia, B.S., Kumar, S. and Ahlawat, M. (2007). Nutrition utilization, excreta moisture, intestinal viscosity of digesta In broiler chicken fed with pearl millet based diet. Animal Nutrition feed Science Technology, 7:197-204

\section{How to cite this article:}

Laxmi Chouhan, S. S. Atkare, A. S. Shinde, S. K. Joshi and Shekhawat, L. S. 2020. Performance of Coloured Broilers with and without Enzymes Supplementation Fed SFC Included Varying Crude Fibre Diets. Int.J.Curr.Microbiol.App.Sci. 9(11): 650-655.

doi: https://doi.org/10.20546/ijcmas.2020.911.080 